DOI 10.37882/2500-3682.2021.05.09

\title{
ПЕРЦЕПЦИЯ МИФОЛОГЕМ СОВЕТСКОЙ ДЕЙСТВИТЕЛЬНОСТИ В СОВРЕМЕННОМ РОССИЙСКОМ СЕРИАЛЕ (НА ПРИМЕРЕ ТЕЛЕСЕРИАЛА «ОБРАТНАЯ СТОРОНА ЛУНЫ»)
}

\section{PERCEPTION OF THE MYTHOLOGEMS OF SOVIET REALITY IN THE MODERN RUSSIAN TV SERIES (ON THE EXAMPLE OF THE TV SERIES "THE OTHER SIDE OF THE MOON")}

D. Vetrov

Summary: In modern Russian society, due to the growing time and cultural gap, a mythological attitude towards the Soviet Union is clearly emerging, which gives rise to the exploitation of certain aspects of the image of the USSR in audiovisual culture. The purpose of this article is to identify and analyze neo-mythological manifestations in the reception of the image of the late USSR in the modern audience on the example of the first season of the TV series "The Other Side of the Moon".

Keywords: archetype, ziggurat, Golden Age, myth, neo-mythologism, trickster, image of the USSR.

\author{
Ветров Дмитрий Николаевич \\ старший преподаватель, Институт \\ кино и телевидения ГИТР \\ vetrov.interprete@mail.ru
}

Аннотация: В современном российском обществе, за счет возрастающего временного и культурного разрыва, очевидным образом вырисовывается мифологическое отношение к Советскому Союзу, что дает повод для эксплуатации тех или иных аспектов образа СССР в аудиовизуальной культуре. Цель данной статьи состоит в выявлении и анализе неомифологических проявлений в рецепции образа позднего СССР у современной аудитории на примере первого сезона телесериала «0братная сторона Луны».

Ключевые слова: архетип, зиккурат, Золотой век, миф, неомифологизм, трикстер, образ СсСР.
$\mathrm{B}$ данном исследовании предпринята попытка проанализировать, с точки зрения различных стратегий мифотворчества, отражения фантастического и контраналитического отношение к миру относительно недавнего прошлого.

Сама насыщенность кинотекста мифологическими вкраплениями и аллюзиями дает нам повод рассматривать дискурс данного сериала в контексте мифологизма (и его деконструкции): это и прямое цитирование славянского эпоса (упоминание Стрибога), и наличие антагониста, в котором легко узнается архетипическая фигура трикстера, и даже ложный намек на Эдипов треугольник (ложный, ибо, в отличие от архаического Эдипа, герой Соловьев прекрасно знает, что в новой реальности занял место отца и потому избегает всех контактов с матерью).

Таким образом, мифологический антураж подталкивает нас к рассмотрению диегетического пространства сериала в том числе и в контексте архаичных мифов, и связанной с ними архетипикой.

Фильм открывается преследованием Рыжего маньяка (И. Шибанов), который в результате несчастного случая оказывается вместе с милиционером Соловьевым (П. Деревянко) в реальности брежневского СССР. С точки зрения мифологии, фантастический механизм переноса характерен для проделок трикстера: в кульминации сцены погони мы отчетливо видим тоннель, в который устремляется Соловьев вслед за Рыжим (проводником). Как указывает Хелена Бассил-Морозоу в книге «Трикстер в современном кино», задача трикстера - помочь герою пройти через ряд трансформаций, в частности посредством проведения героев через пограничные состояния и преодоления различных границ, чтобы в итоге вернуть их в исходную реальность, условность которой оказалась нарушена (причем герои в ходе данной авантюры имеют крайне ограниченный контроль над ситуацией)».

Тот факт, что значительный пласт фильмической реальности представлен как болезненный сон Соловьева - измерение, в котором правит Рыжий, - дает повод вспомнить комментарий Юнга к книге Пола Радина, где аналитик утверждает способность сознания «освободиться от притягательности зла» в условиях развитой культуры. Но поскольку «тьма и зло не рассеялись как дым», но лишь утратили энергию и удалились в бессознательное, эта способность сохраняется лишь при здоровом функционировании сознания. «Однако если сознание попадает в критическую ситуацию, скоро становится ясно, что тень не исчезла бесследно, но лишь ждет своего часа, чтобы заявить о себе в виде проекции на другого». 
Таким образом, воспользовавшись травмой героя, Маньяк из реального мира перенял в результате проекции роль трикстера в воображаемом советском мире Соловьева.

С терапевтической точки зрения, действия маньякатрикстера можно рассматривать как своеобразную помощь Соловьеву, не только на пути к исцелению и возвращению в привычный мир; согласно Гаврилову, роль Маньяка может в данном контексте заключаться в том, чтобы «посредством нарушения социальных норм разорвать порочный круг мира, где все предопределено... создавая многовариантность, свойственную в мифах богам хтоническим. Трикстер тем самым работает на переходе от жесткой системы к многовариантной».

Как мы указали, другим поводом для мифологического анализа сериала служит также представленная в сериале (эпизод 6) мифологема эзотерической составляющей современной науки.

Еще Барт, приводя в качестве примера мифологизации существования и деятельности научного сообщества медийный феномен Эйнштейна, который своей работой породил мифологию в отношении нового научного знания, указывает на двоякую сущность ученого, который сочетает в себе механическую рациональность, преодолевающую страх перед непонятным («миф об Эйнштейне помог создать образ знания, целиком заключенного в формулы») и магическую природу открытия, «[воплощающего] в себе старый эзотерический образ науки, целиком заключенный в нескольких знаках». Таким образом, природа научного знания через призму мифологии дает надежду на снятие иррациональности и завесы мрака с непостижимой и враждебной природы.

В сериале эта роль отведена проф. Яблокову, который занят раскопками капища Стрибога в центре Москвы. Рассказ профессора о славянском божестве наводит Соловьева на мысль о ряде совпадений его ситуации с положением человека, попавшего в немилость к Стрибогу, способному выдувать из тела душу и переносить её в чужие тела. Иными словами, именно в комментариях профессора Соловьев видит если не решение, то по крайней мере сложившуюся в научных кругах концептуализацию собственной проблемы).

Притом, слова ученого (профессора археологии: науки, связующей доаналитическую архаику и логоцентристскую современность) - это частичная победа рационального над иррациональным (или по крайней мере приближение к ней, ибо окончательный ответ на загадку своих злоключений Соловьев, как настоящий архетипический герой, вынужден искать самостоятельно: речь идет о «фатальной неизбежности сакрального, которое [ученый] пока не в силах устранить»).
Однако в рамках данного анализа будет рассмотрен лишь аспект эксплуатации возможно самого мифологизированного фрагмента нашей истории: Брежневского СССР, репрезентированного как идеал культурного героя.

При анализе мифологем в сериале «Обратная сторона Луны», несмотря на присутствующие в картине политические атрибуты советского прошлого, мы имеем в виду не столько бартовское понимание мифа как «похищенного языка» с целью «деполитизации слова» или создания какой бы то ни было политической рекламы, но скорее проблематику мифа в понимании А.Ф. Лосева: «Миф есть в словах данная чудесная личностная история».

Мифологическое сознание, согласно А.Ф. Лосеву, не ушло в прошлое, и не было заменено человеком Нового времени на рациональное сознание: мифология с её иррационализмом остается неотъемлемой частью человеческого мировосприятия. «Мифическое творчество никогда прекратиться не может <...> Если говорить не о содержании мифов, а о самом принципе мифологии, $<\ldots>$ я утверждаю, что эта [западная] культура мифологична, как и все на свете <...> Европейская мифология есть один из необходимых диалектических этапов всемирно-человеческой мифологии».

Выделим основные мифологемы, присутствующие в продукте аудиовизуальной культуры, который составляет предмет данного исследования.

Ключевой мифологемой, которую эксплуатирует сериал, является архетип так называемого «Золотого века» применительно к Советскому прошлому. Рассмотрим две главные черты данного архетипа.

А. Субъекты мифа переживают ностальгию. Как иронично отмечает Элиаде, «можно составить очаровательное описание типичных образов, которое бы раскрывало многочисленные личины, за которыми скрывается ностальгия по Раю <...> Люди эпохи Возрождения, также как и люди средних веков и периода классицизма, хранят в памяти мифическое время, когда человек был неиспорченным, совершенным и счастливым».

Неудивительно, что и современное общество располагает подобным ощущением в отношении сравнительно недавнего Советского прошлого. Так, в сериале события, репрезентирующие «настоящее» время (2011 год) отображены исключительно в холодных тонах, в то время как образ Союза в сознании героя Деревянко отображен в теплых тонах. Контраст данных планов повествования нарочито подчеркнут в эпизоде у магазина «Мелодия» («Грампластинки») на Калининском, когда на героя снисходит мгновенное «озарение», при котором 
он воспринимает современный Новый Арбат с вывеской «Супермаркет» в холодных тонах, после чего его мир вновь предстает в теплом колорите. Таким образом, на уровне цветопередачи формируется инстанция, отражающая ностальгический характер отношения к утерянному идеализированному прошлому.

Иные примеры носят вербальный характер. Так, например, в конце первой же серии имеет место диалог с задержанным оппортунистом, в котором главный герой, с высоты современной ему постсоветской эпохи, выражает определенно позитивную оценку советского прошлого на контрасте с миром капитализма.

Б. Люди «золотого века» живут в непосредственной близости с богами.

Одной из важных черт, приписываемых «Золотому веку» является «возможность подняться на Небо и свободно встретиться с богами...», возможность, которая была утеряна «в результате изначального происшествия - "падения" человека, определившего онтологическую перемену собственного состояния человека, а также космический раскол».

Данному аспекту рассматриваемой мифологемы соответствуют эпизоды, описывающие встречи с представителями элиты и известными личностями отечественной культуры и истории. Если даже рассматривать сцену встречи с юным Киркоровым, которому герой дарит пластинку Пугачёвой, и с молодым Михаилом Боярским в ночном дворе собственного дома (историческое несоответствие, поскольку Боярский к 1979 году, по хронотопу данного эпизода, уже был известен по роли д'Артаньяна, и не мог предстать перед Соловьевым как безвестный персонаж) как носящие комический эффект, нацеленный исключительно на зрелищность, существует ряд других моментов, отражающих принципиальную возможность встречи «обычного советского человека» (так герой Деревянко представляется в начале пятой серии) с любым представителем власти и актерской среды.

В четвертой серии капитан Соловьев достаточно легко попадает, после творческого вечера Высоцкого, на квартирник к нему домой, где их вместе запечатлевают на карточке Polaroid.

В конце пятой серии Соловьев случайно встречает будущего лидера государства, Горбачева, в наименее подходящем для этого, с т.з. церемониальной логики, месте: туалете ресторана; и дает тому советы по поводу грядущей перестройки.

Наконец, по итогам собственного расследования, герой лично встречается с высокопоставленным чиновником внутриполитического ведомства (неким Тро- фимовым) перед проходной, и указывает на проступки и маргинальное поведение его внука, что в результате имеет успех.

Подобная возможность контактов «кумиров» и простых граждан, которая представляется фантастической и невозможной в нынешнее время, указывает на воссоздание утопической модели мира на основе образа утерянного прошлого.

В главе «Символика центра» своего сочинения «Космос и история» Элиаде, рассуждая о колоссальных культовых сооружениях древности указывает: «Архитектоническую символику центра можно сформулировать следующим образом: а) Священная Гора, где встречается Небо с Землей, расположена в центре Мира; б) любой храм или дворец <...> есть священная гора, а тем самым и некий центр; в) будучи осью мира, храм рассматривается как точка соприкосновения Неба, Земли и Ада < ... > Зиккурат был вселенской горой: его семь этажей представляли семь небес...».

В начале второй серии герой П. Деревянко, получив по телеприемнику сообщение от напарника из «реального мира», выходит на крышу, чтобы изучить антенну, с которой, в его понимании, должен приходить сигнал. Именно на той крыше мы впервые видим шпиль Останкинской телебашни. В кадре взгляд героя устремлен на шпиль, при том что сам актер словно «опутан» волноводами антенны: эксплицируется некая связь между героем и башней: ведь именно благодаря телеприемникам его друзья, оставшиеся в реальном «настоящем» (2011 года) могут обрести с ним связь.

О том, что башня отныне находится в центре мира - воображаемого Советского Союза, - который герой сконструировал в сознании в результате травмирующего ДТП, свидетельствует иной эпизод из той же второй серии. В кадре, за магазином «Хозтовары», виднеется шпиль Останкинской башни. Стоящий рядом гражданин объясняет Соловьеву, как пройти к магазину «Мелодия», что на проспекте им. Калинина, показывая в левую часть кадра со словами: "Через квартал, возле "Мелодии"». Уже в следующем кадре мы видим героя на Калининском. Совершенно очевидно, что в районе Нового Арбата не существует такого места, из которого была бы видна Останкинская башня, по крайней мере, под тем углом, который мы видим в предыдущем кадре. Но Башня находится в центре воображаемого мира, и вполне может оказаться в центре Москвы, «через квартал» от Арбата.

К каким же выводам позволяет нам прийти данный обзор мифологем? Образ брежневской эпохи (образца 1979 года), представленной в сериале, является не репрезентацией реального исторического времени, но лишь путешествием по ландшафту собственных воспо- 
минаний героя: по времени своего детства, прошедшего в эпоху, где есть основа и смысл. С т.з. экранной культуры современной России, интерпретация образов и мотивов СССР начала 80-х служит эксплуатации ностальгии зрителя, и носит чисто развлекательный характер. Об этом свидетельствует отсутствие аналитики и чистая апелляция к эмоциям аудитории, зрелищность (порой доходящая до эксплуатации боевого искусства, которым мастерски владеет капитан Соловьев).

О том, что воспроизведенный на экране мир - не есть образ реального Союза, но реконструкция воспоминаний главного героя, нам говорит, в частности, смена фокализации.

Так, в четвертой серии, на творческом вечере Высоцкого, происходит смена фокализации с внутренней (с точки зрения Соловьева, смотрящего на Высоцкого из партера концертного зала) на нулевую (Высоцкий звучит на записи в больничной палате). Так, в определенные моменты мы не просто наблюдаем расфокусировку кадра с переносом фокуса на визир (ВКУ) телевизионной камеры (в кадре изображение на визире - цветное, в то время как реальные ВКУ советских телекамер давали монохромное изображение; еще одно подтверждение того, что репрезентируемый мир - вымышленный), в которой продолжаем наблюдать Высоцкого, но и введение нулевой фокализации, когда на экране того же визира возникает сцена больничной палаты, где находится пострадавший в ДТП Соловьев (2011 год), с проигрывателем, из которого льется запись Высоцкого.

Не менее важным является аспект саморепрезентации кинематографической составляющей повествования: как минимум дважды по ходу сюжета герой оказывается на съемочной площадке кинофильма. С точки зрения дискурсивной составляющей, авторская инстанция подчеркивает нереальность событий, творящихся вокруг героя.

В восьмой серии, где герой ведет расследование на съемочной площадке военного кинофильма, Соловьев стоит на линии огня и неоднократно оказывается вблизи разрывающегося снаряда, но при этом остается невредим. Ответ напрашивается сам собой: кино - это иллюзия. Но не иллюзией ли вообще является и сам мир, что Соловьев воздвиг вокруг себя на основе детских воспоминаний?

Обыгрывание вышеупомянутых встреч героя с политиками, звездами экрана и сцены восьмидесятых годов (и иные маркеры интертекстуальности) также носит гротескный характер. Так, в четвертой серии, получив в очередной раз личное сообщение по телеприемнику от сослуживца Андрея, Соловьев, пытаясь ответить ему, выкрикивает его имя в экран, где уже через мгновенье появляется трансляция выступления А. Миронова, читающего «Признание» А.С. Пушкина. Это, на наш взгляд, одно из многочисленных свидетельств развлекательного характера эксплуатации образов Советского прошлого. Комизм находит выражение и в сцене той же серии, когда Соловьева принимают за Высоцкого - сперва поклонница в гримерке, затем восторженная толпа, которая выносит героя на руках из служебного входа дома культуры.

Данные сцены очевидным образом призваны повысить зрелищность сериала в целом, из чего мы делаем вывод о неисчерпаемом богатстве мотивов, которые легко могут быть вырваны из исторического контекста и под тем или иным художественным предлогом войти в основу мифотворчества с целью создания произведения массовой культуры, построенном на легко узнаваемых, и благодаря тому удобных для дальнейшего расширения интертекстуального поля образов и мотивов.

\section{ЛИТЕРАТУРА}

1. Барт Р. Мозг Эйнштейна // Барт Р. Избранные работы: Семиотика: Поэтика: Пер. с фр. / Сост., общ. ред. и вступ. ст. Г.К. Косикова. - М.: Прогресс, 1989. $616 \mathrm{c}$.

2. Гаврилов Д.А. Трикстер. Лицедей в евроазиатском фольклоре. - М.: Социально-политическая мысль, 2006. - 239 с. - С.17

3. Лосев А.Ф. Диалектика мифа / Сост., подг. текста, общ. ред. А.А. Тахо-Годи, В.П. Троицкого.- М.: Мысль, 2001, 558 с. - С.212

4. Радин, Пол. Трикстер. Исследование мифов североамериканских индейцев с комм. К.Г. Юнга и К.К. Кереньи // Пер. с англ. Кирющенко В.В. - СПб.: Евразия, 1999. -288 с. - С.280

5. Элиаде, Мирча. Космос и история. Избранные работы. - М.: Прогресс, 1987. - 313 с. - С.38-39

6. Элиаде, Мирча. Мифы. Сновидения. Мистерии. - М.: Рефл-бук, 1996. - 287. - с.44

7. Bassil-Morozow, Helena. 2011. The Trickster in Contemporary Film, p.29. New York: Routledge 